\title{
Chemical restraint of coatis by the association of Detomidine, Tiletamine and Zolazepam, in allometrically scaled dosages
}

\author{
[Contenção farmacológica de quatis pela associação de detomidina, tiletamina e \\ zolazepam, em doses calculadas por extrapolação alométrica] \\ R.O. Kunz ${ }^{1}$, C. Cardeal ${ }^{1}$, L.E. Riekher Junior ${ }^{1}$, L.G.E. Valle $^{2}$, S.T. Belettini ${ }^{3}$, \\ R. Piau Junior ${ }^{3 *}$, A.M. Quessada ${ }^{3}$, J.R. Pachaly ${ }^{3}$
${ }^{1}$ Aluno de pós-graduação - Universidade Paranaense - Umuarama, PR
${ }^{2}$ Centro Universitário Dinâmica das Cataratas - Foz do Iguaçu, PR \\ ${ }^{3}$ Universidade Paranaense - Umuarama, PR
}

\begin{abstract}
Ten free-living adult coatis (two males and eight females) were chemically restrained with "ZAD-50", a concentrated formulation prepared with the dehydrated content of a Zoletil/50@ vial diluted with $0.25 \mathrm{~mL}$ of $1 \%$ atropine, $0.265 \mathrm{~mL}$ of Dormiun- $\mathrm{V} \AA$, and $2.2 \mathrm{~mL}$ of distilled water, being exactly $3.0 \mathrm{~mL}$. The formula was administered to each animal previously captured and physically contained with a net. The loss of righting reflex (RR) occurred at $2.3 \pm 0.8$ minutes post-injection (MPI), with anesthesia beginning at 4.4 \pm 2.7 MPI. Myorelaxant and analgesia were considered excellent at all moments of the evaluation. Conscious reactions were observed at 78.7 $\pm 22.2 \mathrm{MPI}$, the return of the RR occurred at $101 \pm 18 \mathrm{MPI}$, and normal ambulation was acquired at $137.0 \pm 31.0$ MPI. The mean values of physiological parameters measured every 10 minutes between 10 and 50 MPI were 152.2 heartbeats per minute for heart rate, 66.4 respiratory movements per minute for respiratory rate, $39.2^{\circ} \mathrm{C}$ for rectal temperature, $86.2 \%$ for $\mathrm{SpO}_{2}$ and $14.6 \mathrm{mmHg}$ for systolic blood pressure. In the same times, the EEG registered sinus rhythm. No adverse reactions were observed, and the assessed vital parameters remained compatible with the state of chemical restraint.
\end{abstract}

Keywords: allometry, anesthesia, wild animals, carnivores, mammals

\section{RESUMO}

Dez quatis adultos de vida livre (dois machos e oito fêmeas) foram contidos empregando-se a formulação denominada "ZAD-50". A fórmula foi preparada a partir do conteúdo desidratado de um frasco de Zoletil/50 ${ }^{\circledR}$ diluído em 0,25mL de atropina a 1\%, 0,265mL de Dormiun- $V^{\circledR}$ e 2,2mL de água destilada, obtendo-se volume final de 3,0mL. A associação foi administrada, por via intramuscular, a cada animal capturado e contido fisicamente com puçá, em dose calculada por meio de extrapolação alométrica interespecífica. A perda da reação postural de endireitamento (RPE) ocorreu aos $2,3 \pm 0,8$ minutos pósinjeção (MPI), observando-se início da anestesia aos 4,4+2,7 MPI. Miorrelaxamento e analgesia foram considerados excelentes em todos os momentos da avaliação. Reações conscientes foram observadas aos $78,7 \pm 22,2 \mathrm{MPI}$, o retorno da RPE ocorreu aos 101 $\pm 18 \mathrm{MPI}$, e os animais voltaram à ambulação normal

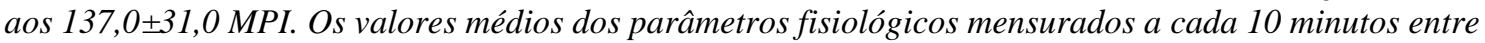
10 e 50 MPI foram 152,2 batimentos por minuto para frequência cardíaca, 66,4 movimentos por minuto para frequência respiratória, $39,2^{\circ} \mathrm{C}$ para temperatura retal, $86,2 \%$ para saturação parcial de oxigênio e $14,6 \mathrm{mmHg}$ para pressão arterial sistólica. Nesses tempos, observou-se ritmo sinusal no eletrocardiograma, e não foram observadas reações adversas.

Palavras- chave: alometria, anestesia, animais selvagens, carnívoros, mamíferos

Recebido em 20 de maio de 2020

Aceito em 1 de setembro de 2020

*Autor para correspondência (corresponding author)

E-mail: piau@prof.unipar.br 


\section{INTRODUCTION}

Coati (Nasua nasua) is a mammal of the Procyonidae Family, Order Carnivora. It is widely distributed in South America and inhabits almost all biomes in Brazil. It is a daytime omnivorous animal provided with strong and sharp teeth, capable of causing severe injuries (Teixeira and Ambrosio, 2007; Beisiegel, 2001). It can measure $30.5 \mathrm{~cm}$ in height, with length varying between 43 and $66 \mathrm{~cm}$, plus 22-69 cm of tail, and body mass can reach $11.0 \mathrm{~kg}$. In reproductive terms, litters are annual (Beisiegel, 2001). Field anesthesia in domestic and wild mammals is essential for performing diagnostic, surgical and dental procedures, and should provide safety for both patient and team involved. Since no single drug is considered ideal, the combination of drugs that both act synergistically and balance undesirable effects of their interaction is sought (Pachaly e VoltarelliPachaly, 2011; Pachaly et al., 2011; Osilhire et al., 2012; Pachaly et al., 2013; Cianca et al., 2014; Ando et al., 2015).

Good quality sedation and myorelaxation are generally obtained using adrenergic receptor agonists ${ }^{2}$, either alone or in combination with dissociative anesthetics, which are the drugs most commonly used in combinations for shortterm injectable anesthesia (Costa et al. , 2010; Pachaly and Voltarelli-Pachaly, 2011; Osilhiri et al., 2012; Pachaly et al., 2013; Cianca et al., 2014; Ando et al., 2015). Such drugs are effective in combating hypertonicity and muscle excitation, often associated with the use of dissociative anesthetics (Augusto et al., 2012).

Of dissociative anesthetics, the most common are ketamine and tiletamine, both commercially available in Brazil. Tiletamine is presented in combination with benzodiazepine zolazepam (Pachaly, 2000), and in doses calculated by means of allometric extrapolation, this association has been used in association with agonists of alpha 2 adrenergic receptors in several species, including horses, rodents and domestic and wild carnivores (Costa et al., 2010; Pachaly and Voltarelli-Pachaly, 2011; Osilhiri et al., 2012; Pachaly et al., 2013; Cianca et al., 2014; Ando et al., 2015). The allometric process allows, through the knowledge of the basal metabolic rates (BMR) of two different vertebrates, to mathematically extrapolate to one of them, drug doses indicated to the other, for which laboratory studies of pharmacokinetic and pharmacodynamic experimentation have already been carried out. The most evident practical objective in veterinary medicine is the extrapolation of drug doses between animals of different shapes, sizes and masses, allowing the use of pharmacological data obtained in a model animal for which the drug was developed and studied, for pharmacotherapy in a target animal, which can be any domestic or wild patient (Pachaly and Brito, 2001; Pachaly, 2006).

The aim of this article was to report the use of the combination of Zoletil / 50® (tiletamine hydrochloride + zolazepam hydrochloride, Virbac, Brazil), atropine sulphate and DormiunV® (detomidine hydrochloride, Agener União, Brazil), at doses calculated through interspecific allometric extrapolation for the pharmacological containment of free-living coatis. For this, these drugs were combined in a concentrated preparation called "ZAD-50" (Zoletil / 50® + Atropine + Dormiun-V®).

\section{MATERIAL AND METHODS}

The project referring to this study was registered at the Research, Studies and Scientific Ambience Institute of the "Paranaense" University (UNIPAR) and approved by the Ethics Research Committee Involving Animal Experimentation at UNIPAR with general registration number 25297. The project also has authorization for activities with scientific purpose number 406962, granted by the Brazilian Ministry of the Environment through the Biodiversity Authorization and Information System (SISBIO / ICMBio).

The work was carried out at the Iguaçu National Park (Foz do Iguaçu, PR) and 10 coatis were used, two males and eight females, with body mass between 3.86 and $8.00 \mathrm{~kg}(5.0 \pm 1.4)$ (Table 1). Coatis were captured and contained for routine procedures in the park, including identification, biometrics, marking, physical examination and collection of biological material samples. Each animal evaluated in the experiment was identified by means of an individual form, which contained identification number, age, sex and biometric data. 
Table 1. Identification of 10 coatis (Nasua nasua) submitted to pharmacological containment to perform various medical procedures using the "ZAD-50" formula (mixture prepared by adding $0.25 \mathrm{~mL}$ of atropine sulfate to $1.0 \% ; 0.265 \mathrm{~mL}$ of Dormiun-V® and $2.2 \mathrm{~mL}$ of distilled water to a Zoletil / 50® bottle) at doses calculated by means of interspecific allometric extrapolation

\begin{tabular}{ccc}
\hline Patient & Sex & $\begin{array}{c}\text { Body mass } \\
(5.0 \pm 1.4 \mathrm{~kg})\end{array}$ \\
\hline 01 & Female & 3.860 \\
02 & Female & 4.200 \\
03 & Female & 4.200 \\
04 & Female & 4.300 \\
05 & Female & 4.500 \\
06 & Female & 4.500 \\
07 & Female & 4.504 \\
08 & Female & 5.000 \\
09 & Male & 7.210 \\
10 & Male & 8.000 \\
\hline
\end{tabular}

Coatis were attracted with fruits and then directly captured with hunting net (Figure 1A). Once in the net, whose weight was previously known, the body mass of each animal was measured using a digital hook scale. Leather gloves were used by the team in order to facilitate the handling of animals inside the hunting net. Using the allometric extrapolation method based on body mass variation known for coatis and the energy constant for their taxonomic group, the doses of the association of drugs to be administered to each individual were calculated. The association consisted of tiletamine hydrochloride and zolazepam (Zoletil®), atropine sulphate and detomidine hydrochloride (Dormiun-V®). For Zoletil / 50® and atropine, the model animal was the $10.0 \mathrm{~kg}$ domestic dog, and model doses were $5.0 \mathrm{mg} / \mathrm{kg}$ and $0.05 \mathrm{mg} / \mathrm{kg}$, respectively. For Dormiun-V®, the model animal was domestic horse of $500.0 \mathrm{~kg}$, and the model dose was $0.02 \mathrm{mg} / \mathrm{kg}$.

Drugs were combined in a concentrated preparation called "ZAD-50" (Zoletil ${ }^{\circledR}+$ Atropine + Dormiun-V®), to which the dehydrated tiletamine and zolazepam content of a bottle of Zoletil / 50®, volumes of $0.25 \mathrm{~mL}$ of $1 \%$ atropine sulfate, $0.265 \mathrm{~mL}$ of Dormiun-V® and $2.2 \mathrm{~mL}$ of distilled water were added. With this combination, final volume in the flask of exactly $3.0 \mathrm{~mL}$ of "ZAD-50" is obtained, as indicated in literature (Pachaly and Voltarelli-
Pachaly, 2011; Osilhiri et al., 2012; Pachaly et al., 2013; Cianca et al., 2014; Ando et al., 2015).

Allometric calculations generated a table of "ZAD-50" doses in milliliters ( $\mathrm{mL}$ ) for administration in animals with body mass between 1.0 and $10.0 \mathrm{~kg}$ (Table 2). Once the mass of each animal after its capture was known, the stipulated dose was intramuscularly administered (IM) deep into the semimembranosus muscle using $0.5 \mathrm{~mL}$ disposable syringe provided with $25 \times 0.7 \mathrm{~mm}$ needle. The injection time was considered time zero, when the timer was started. All subsequent procedures were performed in post-injection minutes (PIM). After "ZAD-50" administration, each animal was kept under clinical evaluation with all data recorded in a follow-up and monitoring form. The time interval between "ZAD-50" administration and loss of the righting reflex reaction (RRR), time between the loss of RRR and the first attempt of the animal in decubitus position to raise its head (conscious reactions) and return to RRR was evaluated.

Once loss of RRR was verified, the clinical evaluation of animals was performed, with physical examination (visual inspection of the tegument, oral cavity and mucous membranes, palpation and percussion of chest and abdomen), body temperature evaluated by rectal thermometry, heart and respiratory rates evaluated by stethoscope (Figure 1B), partial oxygen saturation evaluated by pulse oximetry (Figure 1C), blood pressure evaluated by means of vascular doppler and sphygmomanometer (Figure 1D) and cardiac rhythm evaluated by electrocardiography (Figure 1E). During the containment period, biological materials (blood, hair, ectoparasites, feces, urine and secretions) were also collected for other experiments.

Anesthetic examination was based on the method proposed in literature (Pachaly et al., 2014a) for wild animals, consisting the nociception and myorelaxation assessment. Data referring to physical and anesthetic examinations were evaluated at intervals of 5, 10, 20, 30, 40, 50 and 60 PIM. Nociception was tested by response to the clamping of the second single-digit phalanx of both thoracic and pelvic limbs, with hemostatic clamp without ratchet, which was pressed until intense compression of the digit was perceived. Analgesia was considered 
excellent when there was no sensitivity reaction, good when there was moderate painful reaction with slight resistance to tests, and poor when painful reaction was intense and characterized by situations of evident discomfort, such as total limb flexion, head movement and vocalization.

Myorelaxation was assessed by the degree of extensor stiffness, resistance of both thoracic and pelvic limbs to manipulation and by muscle tone. Myorelaxation was considered excellent when total loss of muscle tone with absence of tremors and / or stiffness was observed, good when there was moderate maintenance of muscle tone, and poor when the animal presented intense movement. In order to determine the quality of the pharmacological containment, the state of immobility and myorelaxation were considered, observed every 10 PIM throughout the procedure. Containment was considered excellent when the animal had excellent muscle relaxation and total immobility, good when the animal had good muscle relaxation and discreet voluntary movement, and poor when the animal presented low muscle relaxation and voluntary movement that indicated the need for physical containment. Under these occasions, salivary flow and pupillary diameter were also assessed.

Shortly after anesthetic evaluation performed at 50 PIM, each animal was placed in a screened transport box, observing recovery at distance until the moment when it fully recovered the ambulation capacity. Recovery quality was considered excellent when the animal rested quietly until awakening, good when it presented moderate psychomotor excitement and poor when it presented agitation, tremors, myoclonus or generalized seizures. Once fully recovered, the animal was transported in the box to the same place where it had been captured and released in the natural environment, being visually observed while remaining close to the team.

Table 2. Doses in $\mathrm{mL}$ of "ZAD-50" (mixture prepared by adding $0.25 \mathrm{~mL}$ of $1.0 \%$ atropine sulphate; $0.265 \mathrm{~mL}$ of Dormiun-V® and $2.2 \mathrm{~mL}$ of distilled water to a bottle of Zoletil / 50®) calculated using interspecific allometric extrapolation, indicated for intramuscular administration in the pharmacological containment of coatis with body mass between 0.1 and $10.0 \mathrm{~kg}$

\begin{tabular}{cccccccc}
$\begin{array}{c}\text { Body mass } \\
(\mathrm{Kg})\end{array}$ & $\begin{array}{c}\text { ZAD-50 } \\
(\mathrm{mL})\end{array}$ & $\begin{array}{c}\text { Body mass } \\
(\mathrm{Kg})\end{array}$ & $\begin{array}{c}\text { ZAD-50 } \\
(\mathrm{mL})\end{array}$ & $\begin{array}{c}\text { Body mass } \\
(\mathrm{Kg})\end{array}$ & $\begin{array}{c}\text { ZAD-50 } \\
(\mathrm{mL})\end{array}$ & $\begin{array}{c}\text { Body mass } \\
(\mathrm{Kg})\end{array}$ & $\begin{array}{c}\text { ZAD-50 } \\
(\mathrm{mL})\end{array}$ \\
\hline 0.10 & 0.0190 & 2.60 & 0.2186 & 5.10 & 0.3622 & 7.60 & 0.4886 \\
0.20 & 0.0319 & 2.70 & 0.2248 & 5.20 & 0.3676 & 7.70 & 0.4934 \\
0.30 & 0.0433 & 2.80 & 0.2310 & 5.30 & 0.3728 & 7.80 & 0.4982 \\
0.40 & 0.0537 & 2.90 & 0.2372 & 5.40 & 0.3781 & 7.90 & 0.5030 \\
0.50 & 0.0635 & 3.00 & 0.2433 & 5.50 & 0.3834 & 8.00 & 0.5077 \\
0.60 & 0.0728 & 3.10 & 0.2494 & 5.60 & 0.3886 & 8.10 & 0.5125 \\
0.70 & 0.0817 & 3.20 & 0.2554 & 5.70 & 0.3938 & 8.20 & 0.5172 \\
0.80 & 0.0903 & 3.30 & 0.2613 & 5.80 & 0.3989 & 8.30 & 0.5220 \\
0.90 & 0.0986 & 3.40 & 0.2673 & 5.90 & 0.4041 & 8.40 & 0.5267 \\
1.00 & 0.1067 & 3.50 & 0.2731 & 6.00 & 0.4092 & 8.50 & 0.5314 \\
1.10 & 0.1146 & 3.60 & 0.2790 & 6.10 & 0.4143 & 8.60 & 0.5360 \\
1.20 & 0.1224 & 3.70 & 0.2848 & 6.20 & 0.4194 & 8.70 & 0.5407 \\
1.30 & 0.1300 & 3.80 & 0.2905 & 6.30 & 0.4245 & 8.80 & 0.5454 \\
1.40 & 0.1374 & 3.90 & 0.2962 & 6.40 & 0.4295 & 8.90 & 0.5500 \\
1.50 & 0.1447 & 4.00 & 0.3019 & 6.50 & 0.4345 & 9.00 & 0.5546 \\
1.60 & 0.1519 & 4.10 & 0.3075 & 6.60 & 0.4395 & 9.10 & 0.5593 \\
1.70 & 0.1589 & 4.20 & 0.3132 & 6.70 & 0.4445 & 9.20 & 0.5639 \\
1.80 & 0.1659 & 4.30 & 0.3187 & 6.80 & 0.4495 & 9.30 & 0.5684 \\
1.90 & 0.1727 & 4.40 & 0.3243 & 6.90 & 0.4544 & 9.40 & 0.5730 \\
2.00 & 0.1795 & 4.50 & 0.3298 & 7.00 & 0.4594 & 9.50 & 0.5776 \\
2.10 & 0.1862 & 4.60 & 0.3353 & 7.10 & 0.4643 & 9.60 & 0.5821 \\
2.20 & 0.1928 & 4.70 & 0.3407 & 7.20 & 0.4692 & 9.70 & 0.5867 \\
2.30 & 0.1994 & 4.80 & 0.3461 & 7.30 & 0.4740 & 9.80 & 0.5912 \\
2.40 & 0.2058 & 4.90 & 0.3515 & 7.40 & 0.4789 & 9.90 & 0.5957 \\
2.50 & 0.2122 & 5.00 & 0.3569 & 7.50 & 0.4837 & 10.00 & 0.6002 \\
\hline
\end{tabular}




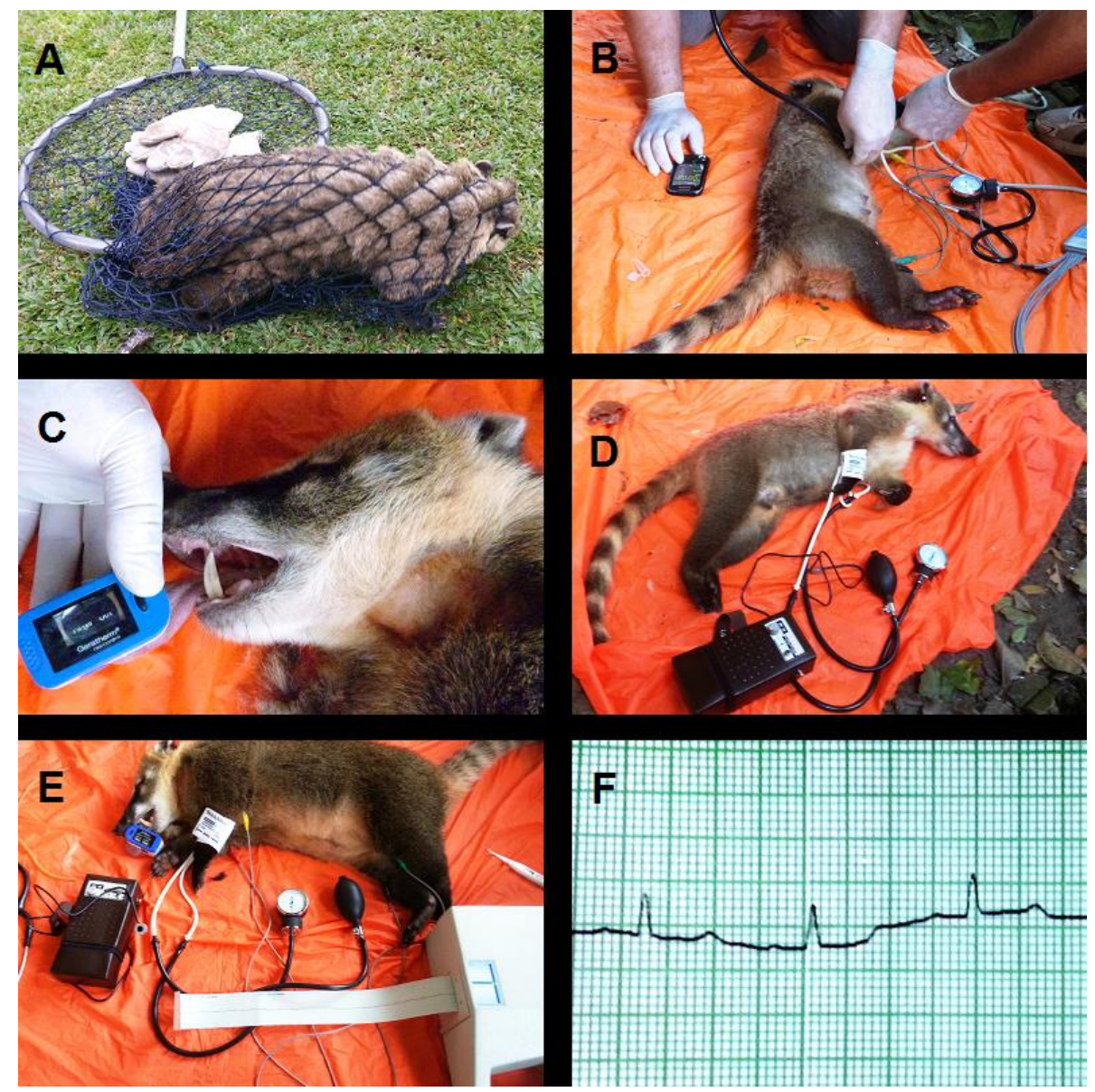

Figure 1. A. Photographic image of female coati (Nasua nasua) with body mass of $4.50 \mathrm{~kg}$, immediately after being captured using hunting net. B. The same animal under pharmacological containment using the "ZAD-50" association (Zoletil / 50® + Atropine + Dormiun-V®) at dose calculated by means of interspecific allometric extrapolation. Heart rate monitoring was observed through chest auscultation with stethoscope. C. The same animal, with monitoring by means of pulse oximetry, with sensor connected to the animal's tongue. D. The same animal, observing blood pressure monitoring by means of vascular doppler and sphygmomanometer. E. The same animal, observing the electrocardiography test. F. Photographic image of the electrocardiographic tracing obtained on the same animal, showing sinus rhythm (Foz do Iguaçu - PR, 2014).

All data obtained were tabulated using the MSExcel software and submitted to statistical analysis using the Statistica for Windows software. Data referring to loss of righting reflex reaction, heart rate, respiratory rate, rectal temperature, beginning of awakening, moment of manipulation impossibility, moment of awakening and return to normal ambulation were expressed by means and standard deviations of estimates. The Spearman test determined the existence of correlation between monitored parameters and time throughout the containment process. Analysis of variance (ANOVA) was performed using the Tukey test to evaluate the existence of differences in the values of these parameters, measured over time.

\section{RESULTS}

Loss of RRR occurred at $2.3 \pm 0.8$ PIM, and anesthesia started at $4.4 \pm 2.7$ PIM. Myorelaxation and analgesia were considered excellent at all times between 10 and 50 PIM. Conscious reactions were observed at $78.7 \pm$ 22.2 PIM and return to RRR occurred at $101 \pm$ 18 PIM. Animals returned to normal ambulation at $137 \pm 31$ PIM. Several parameters were assessed over time (Table 3). 
Table 3. Evolution of parameters heart rate, respiratory rate, rectal temperature, partial oxygen saturation $\left(\mathrm{SpO}_{2}\right)$ and systolic blood pressure in 10 animals (Nasua nasua) anesthetized by pharmacological association called "ZAD-50" (Zoletil / 50® + Atropine + Dormiun -V®) at dose calculated by means of interspecific allometric extrapolation, between 10 and 50 post-injection minutes (PIM)

\begin{tabular}{cccccc}
\hline Time $(\mathrm{PIM})$ & $\mathrm{HR}(\mathrm{bpm})$ & $\mathrm{RR}(\mathrm{mpm})$ & $\mathrm{RT}\left({ }^{\circ} \mathrm{C}\right)$ & $\mathrm{SpO} 2(\%)$ & $\mathrm{SBP}(\mathrm{mmHg})$ \\
\hline 10 & $161 \pm 26$ & $56 \pm 22$ & $39.6 \pm 0.6$ & $87 \pm 9.0$ & $140 \pm 10$ \\
20 & $158 \pm 18$ & $70 \pm 22$ & $39.6 \pm 0.6$ & $86 \pm 11$ & $140 \pm 10$ \\
30 & $152 \pm 10$ & $67 \pm 19$ & $39.3 \pm 0.7$ & $87 \pm 10$ & $150 \pm 10$ \\
40 & $147 \pm 07$ & $65 \pm 16$ & $38.9 \pm 0.7$ & $85 \pm 7.0$ & $150 \pm 10$ \\
50 & $143 \pm 10$ & $74 \pm 17$ & $38.7 \pm 0.9$ & $86 \pm 4.0$ & $150 \pm 10$ \\
\hline
\end{tabular}

During the evaluation period, sinus rhythm was observed through electrocardiographic examination (Figure 1F), and no changes were observed for salivary flow and pupillary diameter. In the statistical evaluation by Spearman's test, heart rate showed significant negative correlation with time ( $\mathrm{rs}=-0.3621$; $\mathrm{P}=0.0097$ ), falling over time. Applying analysis of variance (ANOVA) using the Tukey test, significant difference in the number of heartbeats between 10 and 50 PIM was observed $(\mathrm{P}<0.05)$.

Regarding respiratory rate, data analysis using the Spearman test did not show significant correlation between time and respiratory rate (rs $=0.2561, \quad \mathrm{P}=0.0726)$. When analyzing respiratory rate using ANOVA, no significant differences were observed in the number of respiratory movements over time $(\mathrm{P}=0.3532)$. Regarding rectal temperature, correlation with time was significantly negative ( $\mathrm{rs}=-0.4534$, $\mathrm{P}=0.0009$ ), falling over time. Using ANOVA and the Tukey test, significant drop in temperature was observed at 40 and 50 PIM $(\mathrm{P}<0.05)$. Regarding partial oxygen saturation, no significant correlation was observed by the Spearman test ( $\mathrm{rs}=-0.1141 ; \mathrm{P}=0.4301)$, and also with ANOVA, no significant difference was observed $(\mathrm{P}=0.9687)$. Finally, regarding blood pressure, no correlation was observed with time using the Spearman test ( $\mathrm{rs}=0.1515 ; \mathrm{P}=0.2936)$, and no differences were observed using ANOVA $(\mathrm{P}=0.7174)$.

\section{DISCUSSION}

The "ZAD-50" combination has final volume of $3.0 \mathrm{~mL}$ after preparation, with tiletamine, zolazepam, atropine and detomidine drugs associated at high concentrations in the form of a combination prepared and calculated in order to offer practicality and safety to the veterinarian in field anesthesia situations. The method presented here followed Pachaly's and Voltarelli-Pachaly indications (2011) for lions, Osilhire et al. (2012) for jaguars, Ando et al. (2015), for domestic cats, Cianca et al. (2014) for domestic dogs, and Pachaly et al. (2014b)) for Syrian hamsters. The good results obtained by such authors were also observed in this study, which also corroborates data from a preliminary study carried out on coatis by Pachaly et al. (2013).

The method used proved to be safe and efficient for field anesthesia in 10 coatis (Nasua nasua), two males and eight females, with body mass between 3.86 and $8.00 \mathrm{~kg}(5.0 \pm 1.4)$, submitted to pharmacological containment to collect blood, hair, and ectoparasites, material collection by rectal swab and electrocardiographic examination. No adverse reactions were observed, and the vital parameters evaluated remained within standards compatible with the state of general anesthesia. With post-anesthetic recovery, the practicality of the method and its full applicability were demonstrated, providing simplification to the routine of the field veterinary work

In view of the short period of time to start the state of pharmacological containment at $2.3 \pm 0.8$ PIM and onset of anesthesia at $4.4 \pm 2.7$ PIM, it was concluded that the "ZAD -50" anesthetic association allows lower capture stress, contributing to the animals' well-being. This study was carried out under real conditions of work of managing free-living coatis in parks and nature reserves, and the pharmacological containment of all animals was fully satisfactory. No adverse reactions were observed, and the vital parameters evaluated remained within standards compatible with the state of pharmacological containment, with return to normal life. 
The method is innovative and has potential to be used in a large number of domestic and wild species, aiming at practicality and safety in the veterinary environment in situations where ideal standards of facilities and equipment are not available. In addition, the protocol is an excellent form of pre-anesthetic medication in situations that require complex and time-consuming surgeries, allowing all the procedures necessary to induce both intravenous and inhalation total anesthesia.

\section{ACKNOWLEDGMENTS}

To the Executive Board for Research Management and Graduate Studies at "Paranaense" University (DEGPP - UNIPAR), for the granting of financial assistance and master's scholarship from the Institutional Teacher and Technical-Scientific Training Program (PIT). To the Board and technical staff of the Iguaçu National Park, for supporting the conduction of this field work.

\section{REFERENCES}

ANDO, M.R.; CIANCA, R.C.; BELETTINI, S.T. et al. Novo método para contenção farmacológica e anestesia de campo em gatos domésticos (Felis catus), empregando a fórmula "ZAD-50" (Zoletil/50® + Atropina + Dormiun-V®). Medvep, v.13, p.54-61, 2015.

AUGUSTO, L.E.F.; FAVARATO, L.S.C.; OLIVEIRA, T.T.; et al. Uso de Hypericum perforatum L. em associação à cetamina na anestesia de ratos Wistar. J. Bras. Ciênc. Anim., v.5, p.346-356, 2012.

BEISIEGEL, B.M. Notes on the coati, Nasua nasua (Carnívora: Procyonidae) in an Atlantic Forest area. Braz. J. Biol., v.61, p.689-692, 2001.

CIANCA, E.C.; ANDO, M.R.; BELETTINI, S.T. et al. Novo método para contenção farmacológica e anestesia de campo em cães domésticos (Canis familiaris) empregando a fórmula "ZAD-50" $($ Zoletil $/ 50 \AA$ + Atropina + Dormiun-V®). Medvep, v. 12, n. 40 p. $150-158,2014$.

COSTA, F.A.; BELLETINI, S.T.; AMARANTE, J.N.S. et al. Avaliação comparativa entre as associações de tiletamina e zolazepam a romifidina ou detomidina, em doses calculadas por extrapolação alométrica, para anestesia de campo em cavalos (Equus caballus). Hora Vet., v.29, p.34-40, 2010.
OSILHIRI, Jr, J.A.; PEREIRA, R.L.; HERRERA, D. et al. Novo método para contenção farmacológica e anestesia de campo em onças-pintadas (Panthera onca), empregando a fórmula ZAD (Zoletil/100 + Atropina + Dormiun-V) - relato preliminar. Hora Vet., v.32, p.54-59, 2012.

PACHALY, J.R. Principais drogas empregadas na contenção química de animais selvagens. Arq. Ciênc. Vet. Zool. Unipar, v.3, p.87-94, 2000.

PACHALY, J.R. Terapêutica por extrapolação alométrica. In: CUBAS, Z.S.; SILVA, J.C.R.; CATÃO-DIAS, J.L. (Eds.). Tratado de animais selvagens. São Paulo: Roca, 2006. p.1215-1223.

PACHALY, J.R.; BRITO, H.F.V. Interespecific allometric scaling. In: FOWLER, M.E.; CUBAS, Z.S. (Eds). Biology, medicine and surgery of SouthAmerican wild animals. Ames: Iowa University Press, 2001. p.475-481.

PACHALY, J.R.; CARNEIRO, M.R.; ALBERTON, L.R. et al. Contenção farmacológica e anestesia de campo em primatas da família Cercopithecinae empregando a fórmula "ZAX-50" (Zoletil/50® + atropina + xilazina). Medvep, v.9, p.415-459, 2011.

PACHALY, J.R.; DOMINGUES, R.H.; SOUZA, M.V.F. Novo método para contenção farmacológica e anestesia de campo em quatis (Nasua nasua), empregando a fórmula "ZAD-50" (Zoletil/50® + Atropina + Dormiun-V®) - Relato preliminar. Hora Vet., v.33, p.58-62, 2013.

PACHALY, J.R.; MONTEIRO-FILHO, E.L.A.; WERNER, P.R. et al. Cetamina, xilazina e atropina, em doses calculadas por extrapolação alométrica interespecífica, para contenção farmacológica da cutia (Dasyprocta azarae). Arq. Ciênc. Vet. Zool. Unipar, v.17, p.11-26, 2014a.

PACHALY, J.R.; SOUZA, M.V.F.; MONTIANIFERREIRA, F. et al. Emprego da fórmula "ZAD-50" (ZOLETIL/50® + ATROPINA + DORMIUN-V®) para anestesia dissociativa em procedimento de enucleação com acesso transconjuntival de bulbo ocular proptótico em hamster sírio (Mesocricetus auratus) - relato de caso. Hora Vet., v.34, p.58-62, 2014b.

PACHALY, J.R.; VOLTARELLI-PACHALY, E.M. Novo método para contenção farmacológica e anestesia de campo em leões (Panthera leo), empregando a fórmula ZAD (Zoletil/100 + Atropina + Dormiun-V) Relato preliminar. Hora Vet., v.31, p.7580, 2011.

TEIXEIRA, R.H.F.; AMBROSIO, S.R. Carnivora, Procyonidae (mão-pelada, quati, jupará). In: CUBAS, Z.S.; SILVA, J.C.R.; CATÃO-DIAS. J.L. (Eds). Tratado de animais selvagens. São Paulo: Roca, 2007. p.571-573. 